\title{
Assistance The Importance Of Brand Awareness Home Industry "MAYA" In Lumajang
}

\author{
Hesti Budiwati \\ Departement of Management, STIE Widya Gama Lumajang, Indonesia \\ Email: hestibudiwati1404@gmail.com
}

\begin{tabular}{lll}
\hline Submission : & Review : & Publication : \\
$1^{\text {st }}$ April 2020 & $13^{\text {th }}$ June 2020 & $28^{\text {th }}$ Augustu 2020 \\
\hline
\end{tabular}

\begin{abstract}
Abstrak
Home Industry is the smallest unit in a series of existing types of business, where household industries are generally managed independently as a family with the aim of increasing household income. The challenges for this home industry are also not easy. In general, because it is managed in a family environment or in one's own household, sometimes the management tends to be careless and mixed up between family finances and business finances. Starting from this reason, there is an interest in partnering with Hj's home industry salted egg "Maya". Umi Pristiwani in Jogotrunan Village, Lumajang Regency. Partners run their businesses whose main purpose is to help their families' economies. However, until now this partner has only been running his business as he is and has no brand, which means that he does not have a product identity but has a strong desire to move forward. Often partner businesses lose out in competing with other similar businesses. Partners are also not yet able to run their businesses that can create jobs for the surrounding community. The implementation of this community service activity achieves targets, namely (1) building understanding and awareness of the importance of brands for salted egg products, (2) improving partners' skills in running their businesses in a sustainable manner, (3) establishing understanding and the ability of human resources in creating jobs for the surrounding community, and (4) increasing marketing strategies so that they are able to compete in marketing their products. Intensive assistance and supervision to program partners needs to be carried out periodically and does not stop until the completion of this program, therefore the activity of the team and the staff of STIE Widya Gama Lumajang in providing guidance to these partners needs to be carried out on an ongoing basis.
\end{abstract}

\section{Keywords: Home Industry, Brand Awareness, Management.}

\section{INTRODUCTION}

Home Industry is the smallest unit in a series of existing types of business, where the household industry is generally managed independently as a family which aims to increase household income. There are various types of business, which generally produce products for household needs and the surrounding environment. Even though it is on a small scale, if this Home Industry is managed and managed properly, it can help the family economy and support the regional economy. However, the challenges for this home industry are also not light. In general, because it is managed in a family environment or in one's own household, sometimes the management tends to be careless and mixed up between family finances and business finances. 
This problem also occurs in this community service partner, namely the salted egg home industry "Maya" which is managed by the Hj family. Umi Sri Pristiwani in Lumajang. The conditions for this salted egg business which is managed simply with the family are actually quite productive. However, the modest management makes this business less able to develop optimally. Based on our observations, $\mathrm{Hj}$. Umi Sudibyo actually has promising future prospects, however, until now this business has not been able to develop optimally. Marketing is only carried out on activities in the surrounding environment, for example at meetings during recitation or PKK only. Unbranded products are also a problem in this business. Actually, the quality of salted egg products is quite liked by consumers around.

Based on the results of a brief interview with $\mathrm{Hj}$. Umi Sri Pristiwani as the owner of this business, actually the salted egg product used to have a name, namely "Maya" according to the name of her daughter. But in its development this brand sank because of $\mathrm{Hj}$. Umi Sri Pristiwani is also reluctant to promote this brand name and even more so reluctant to take care of licensing her salted egg product brand. This is very unfortunate because until now the salted egg product is finally on the market without carrying the brand. So that quite a lot of people still have to wonder about whose salted egg products they have consumed. Based on these conditions, we were moved to provide assistance in providing an understanding of the importance of brand awareness and effective marketing in this home industry. It turned out that our partners welcomed the implementation of this assistance.

This spirit of progress and development is the basis for consideration of holding community service activities in the form of mentoring the importance of brand awareness and effective marketing in Hj's salted egg home industry. Umi Sri Pristiwani. Berdasarkan survey awal dan analisis situasi yang telah dilakukan, kelompok ini mempunyai permasalahan sebagai berikut : 1 . Kurangnya kesadaran akan pentingnya merek bagi produk telur asin yang dihasilkan. 2. Terbatasnya kemampuan sumber daya manusia dalam mengelola manajemen usahanya. 3. Lemahnya strategi pemasaran yang digunakan sehingga berakibat keuntungan yang diperoleh sedikit, usaha kurang berkembang dengan baik karena cenderung kalah dalam persaingan. Selanjutnya pembicaraan formal dengan kelompok mitra ini menghasilkan kesepakatan bahwa mitra menginginkan bisa mengembangkan usahanya, dan mampu menciptakan lapangan pekerjaan bagi masyarakat sekitarnya.

The solutions offered in service activities to the home industry of salted egg "Maya" owned by Hj. Umi Sri Pristiwani is as follows: 1. Build awareness of the importance of brands for salted egg products. 2. Increase the ability of human resources in managing business management. 3. Establishing the ability of human resources to create jobs for the surrounding community. 4. Strengthening the marketing strategy so that it can compete in marketing its products.

This community service activity is expected to produce targets in accordance with partner expectations, as follows: 1. Built understanding and awareness of the importance of brands for salted egg products. 2. Increasing partners' skills in running their businesses in a sustainable manner. 3. Understanding and the ability of human resources to create jobs for the surrounding community is formed. 4. Increasing marketing strategies so that they are able to compete in marketing their products. This community service activity that involves Lecturers is expected to become an arena for Lecturers to carry out one of the Tri Dharma of Higher Education, namely in the field of community service and applying the knowledge they have to share with the community in reality.

\section{IMPLEMENTATION METHODS}


How can partners who have a strong desire to develop and are able to create jobs for the surrounding community become the main priority that will be resolved through community service programs? The limited skills of partners in managing their business and creating jobs for the surrounding community are a big problem for partners, so they need solutions that are simple and affordable for them. Lecturer at STIE Widya Gama Lumajang, who has full support for carrying out community service activities, tries to provide simple solutions for their desire to develop their business. Some of the steps set out in this service activity to answer partner problems are as follows: 1. The first step, which was agreed upon to find a solution to the existing problems, was to provide assistance to understand meek's awareness of the salted egg products produced. 2. The second step, which was agreed upon to find solutions to the existing problems, was to implement effective marketing management assistance activities. 3. The third step, providing operational funding for brand administration and operations. 4. The fourth step, no less important is the monitoring and evaluation of the Lecturer team of STIE Widya Gama Lumajang so that partners can independently run their business well and are able to create jobs for the surrounding community. The implementation of monitoring and evaluation does not only stop at the service period, but monitoring and evaluation activities are carried out continuously through community service programs implemented and developed by STIE Widya Gama Lumajang. All of these stages require assistance that is patient, serious and intensive so that the spirit that has been built does not decline because the real challenges in the real competition that will be faced are not light, both in financial aspects, marketing aspects, production aspects and management.

The implementation method that will be carried out to solve the problems of the partner group consists of the following steps: 1. Brand awareness assistance. The purpose of this brand awareness assistance is to prepare partners to understand that a brand is needed as the identity of its product so that in the end the product will be easily recognized by the public. 2. Delivery of Operational Funds Assistance. The activity of handing over grants to provide operational funds for brand administration and operations. 3. Monitoring and Evaluation. A process that is no less important is monitoring and evaluation which will be carried out periodically until the partners can independently run their business in a sustainable manner so that the overall goals, targets and outputs of this PKM activity can be achieved properly.

The first activity is designed by approaching and sharing with partners, because to carry out this activity properly it will really require their full support to provide an understanding of the importance of the benefits of this community service activity for partner businesses, especially the support of time, energy and thoughts where partner members must focus on carrying out these activities and taking the time. The second activity is designed to prepare mentoring on the importance of brand awareness and effective marketing management where the material will be compiled and given by STIE Lecturer Widya Gama Lumajang. The third activity is designed to provide assistance, monitoring and evaluation to help provide solutions to problems that occur, until the partners are truly independent and can carry out their business properly and sustainably. This activity will be held at the location of Hj's "Maya" home industry. Umi Sri Pristiwani, located on Jl. Mahakam, Jogotrunan Village, Lumajang District, Lumajang Regency. The fourth activity is the preparation of reports on community service activities, which is carried out by compiling a draft progress report and final report, conducting seminars on the results of activities and if necessary, revising the final report and compiling scientific articles as scientific journal material.

\section{RESULTS AND DISCUSSION}


The measure of the success of the Mentoring activity on the Importance of Brand Awareness in Salted Egg Home Industry Partners "Maya" in Jogotrunan Village, Lumajang District, Lumajang Regency is the achievement of the targets set as follows: 1. Built understanding of the importance of brand awareness for partners. 2. Increasing partners' skills in running their businesses in a sustainable manner. 3. Understanding and the ability of human resources to create jobs for the surrounding community is formed. 4. Increasing marketing strategies so that they are able to compete in marketing their products.

This community service activity can produce outcomes in accordance with partner expectations, namely: 1 . Immediately formed a brand for partner-owned salted egg products. 2. Human resources who are skilled in running their business. 3. The ability of partners in creating jobs for the surrounding community. 4. Proper and orderly business management.

\section{CONCLUSION}

Several things can be concluded in the implementation of Assistance on the Importance of Brand Awareness in Home Industry Partners of Salted Egg "Maya" owned by $\mathrm{Hj}$. Umi Sri Pristiwani in Jogotrunan Village, Lumajang District, Lumajang Regency as follows: 1. Program partners have a strong desire to expand their business, given the sharp competition in similar businesses in Lumajang. Limitations in managing management and the ability to create jobs for the surrounding community are a problem for partners who need solutions to this activity. 2. Community service activities carried out are able to provide simple solutions to develop partner businesses in a sustainable and competitive manner. 5 . The achievement of targets which are a measure of the success of this community service activity, namely 1) building understanding and awareness of the importance of brands for salted egg products, (2) improving partners' skills in running their businesses in a sustainable manner, (3) forming understanding and ability of human resources in creating jobs for the surrounding community, and (4) increasing marketing strategies so that they are able to compete in marketing their products. 3 . This community service activity can produce output in accordance with partner expectations, namely (1) soon to form a brand for salted egg products owned by partners, (2) skilled human resources in running their business, (3) the ability of partners to create jobs for the surrounding community, and (4) proper and orderly business management.

The biggest challenge for partners is actually when they really face this business competition. Therefore, there are several suggestions so that this activity can provide sustainable benefits, as follows: 1. There needs to be a high level of enthusiasm and willingness for partners to develop themselves by equipping themselves with increased skills in both their ability to innovate and their management abilities. 2. The challenge of competition which is quite fierce must be balanced with a positive mentality and attitude and a high spirit of never giving up, because if the program partners do not have a strong entrepreneurial spirit and ability to innovate, they will be easily crushed by the level of similar business competition. 3. Intensive assistance and supervision to program partners needs to be carried out periodically and does not stop until the completion of this program, therefore the activeness of the STIE Widya Gama Lumajang community in providing guidance to this UKM needs to be carried out on an ongoing basis. 4. It is hoped that further funding for this activity needs to be implemented to help other small businesses of the same type to be able to innovate and be able to develop in increasingly sharp business competition and to create jobs for the surrounding community. 


\section{REFERENCES}

Apriyanto, Y. dkk. (2008). "Kearifan Lokal dalam Mewujudkan Pengelolaan Sumberdaya Air yang Berkelanjutan". Makalah Pada PKM IPB, Bogor.

Badan Pusat Statistik Kabupaten Lumajang. (2014). Kabupaten Lumajang Dalam Angka, Lumajang Regency In Figures 2014. ISSN:0215.5648. BPS Kabupaten Lumajang.

Wibowo dan Nulhaqim. (2015). Kewirausahaan Sosial. Unpad press. ISBN: 978-602-081001-0. Bandung.

Zakaria, W. A. (2008). Dinamika Pembangunan Pertanian dan Perdesaan, Pusat Analisis Sosial Ekonomi dan Kebijakan Pertanian. Departemen Pertanian. 